\title{
Effect of Using an Educational Strategy on Performance level of the Overhead Serve and Underhand Serve Skills in Volleyball
}

\section{"Dr/ Ayat Abdel-Halim Mohamed}

Introduction

Working to provide alternatives for methods, techniques and content are very important means to find alternative paths for learners, so the efficient teacher is the more flexible one to move between different strategies and methods with what suit its objectives and the teachers' responses towards the skills that they must perform. In addition, the teacher is the designer of the educational environment. (Mohamed \& Moustafa, 2004), (Moustafa, 2003)

Modern tools, techniques, modern educational strategies and advanced learning concepts have emerged to help us provide effective learning that is appropriate for each student's abilities. There are large numbers of learners working to transform their learning process upside down by replacing their classes and traditional lectures with educational videos. This process is known as flipped learning or flipped classes and has been described as the future of education by many interested in the development of teaching methods and strategies. (Davis 2012)

In addition, technology has contributed to changing lifestyles among individuals through the rapid spread of smart mobile technology, making teachers and educators think of developing a new technology-based approach to solving some of the challenges and constraints they face in education. This has convinced educators that The teaching system is unable to achieve long-term learning goals. There are other methods of learning that are more effective and help to keep information for long periods compared with the lecture, including the flipped learning strategy. (Bergmann, Sams 2012)

Baker (2010) generally is credited with

* Department of Sports Games Training, Faculty of Physical Education for Girls in Gizepa,Helwan University, Arab Republic of Egypt Corresponding author Assiut Journal For Sport Science Arts 
conceptualizing the flipped learning paradigm, although other teachers have used the inverted instructional method with success (Lage \& Platt, 2012; Lage, Platt, \& Treglia, 2012). In 1995, Baker, a professor at a small private university in Ohio with access to a school-wide Internet site, asked his communication students to view his PowerPoint slides prior to coming to class. He wanted the students to absorb the factbased content ahead of time so that he could focus on the 2 students' in-class active learning. He "saw the 'Flip' as a way of addressing the 'covering the content' debate" (Baker, 2010, p. 3) and believed that it allowed him to quickly disseminate direct instruction while preserving class time for active learning. He presented the idea for the concept at various conferences until the moniker "the flipped learning" (Baker, 2010, p. 3) took hold. (Lage \& Platt, 2012), (Lage, Platt, \& Treglia, 2012), (Baker 2010)

The flipped learning is a blended learning model characterised by the expectation that students are exposed to content before class so they are prepared for active learning in class. Active learning strategies have been shown to improve student engagement and present a variety of opportunities for formative assessment and feedback. (Bergmann, Sams 2012)

The potential benefits of flipped learning:

- By providing students with the material to gain a basic level of knowledge and understanding before class.

- Classroom time can be used to deepen learning and develop higher-level cognitive skills.

- One of the core objectives of flipped learning is to move students away from passive learning and towards active learning where students engage in collaborative activity, peer learning and problem-based learning.

- Within this context, the role of the teacher shifts towards that of facilitator and coach by empowering students to take control of their own learning.

- The use of technology further enriches the flipped learning process and promotes skills that are essential for 21 stcentury learning (e.g. digital literacies) where the flipped classroom approach within 
education is only becoming more popular among educators in both K-12 and higher-ed environments. (Hamdan, McKnight, P., McKnight, K. and Arfstrom 2013)

Guidance on how to use the flipped classroom model, (Justin 2016) are as follows:

Step 1: Empower the Student In this step, you should focus on creating a studentcentered learning environment. By doing this, the teacher becomes more of a guide to the learning. (Justin 2016)

Step 2: Utilize Technology With your learning management system in place, you allow students to easily access the course material at any point in time and from any location. Post videos of lectures, share the educational group or online study guides and reading materials, insert audio, images, and any media you can think of for students to access. (Justin 2016)

Step 3: Always Evaluate

Having your program in place is one thing - you also need to keep an eye on how it is performing by regularly evaluating learning outcomes and adapting accordingly. If monitored properly, you should see a positive impact on performance over time.

In fact, in one study,(http://echo360.com/case -study/unc-chapel-hill) $\quad 200$ teachers using flipped learning, and $85 \%$ of them saw an overall increase in grades. (Justin 2016)

Step 4: Foster a Learning Community

Just posting your content online or will not guarantee that it is effective. You should do everything in your control to foster a community among the students. Encourage interaction with the content that is posted, ignite discussions, and solicit feedback. (Justin 2016)

Accordingly, in the flipped model (the flipped learning), direct instruction and fact-based content is delivered via video lectures that students watch outside the classroom, while activities and activelearning strategies are conducted inside the classroom. In other words, students do homework and activities at school and hear traditional lectures at home via videos. (Lajoie, Azevedo 2006) On the other hand, the researcher observation during her work at the Faculty of 
physical education that methods and means used to learn learning skillful aspects in volleyball lacks the motivation of the learner and the desire to learn more skills, as period after using these methods the learner sense monotony and boredom, these traditional methods doesn't commensurate with what the world reached of technological uses and applications in the educational process.

Also, through the practical observation, the researcher noted that overhead, underhand serve skill's performance level for the students in is characterized by randomness, poor performance and lack of coordination in motor sequence, and students cannot develop a correct perception of the skill in mind which leads to weak performance level.

Thus, this study is an attempt to teach students with one of the most modern educational strategies es in the field of volleyball teaching, by designing an educational strategy based on using flipped learning style for studying its effect on volleyball motor skill`s learning.

Reseach objective:
The main aim of this study was designing an educational strategy based on using flipped learning style and monitor its effect on skillful Performance level in volleyball (Overhead serve, Underhand serve skill) for female students of physical education faculty.

\section{Research hypothesis:}

1- There are statistically significant differences between the pre-and post-measurements for experimental group (flipped learning style group) in the skillful level under research in favor to the post measurement. 2- There are statistically significant differences between the pre-and post-measurements for the controlled group (explanation and presentation style group) in the skillful level under research in favor to the post measurement.

3- There are statistically significant differences in post measurements between the two experimental, controlled groups (flipped learning style, explanation and presentation style) in the skillful level under research in volleyball in favor to the experimental group (flipped learning style).

\section{Methodology}

Method:

Assiut Journal For Sport Science Arts 
The experimental approach was used for two groups, one experimental and the other controlled, using prepost measurements for each group.

\section{Research sample:}

The research society consisted of (279) female students of the second class students in faculty of physical education for girls, Helwan university for the academic year 2015/2016. The basic sample was randomly selected from the female students of the research community. The total number of the sample was (80) female students with $28.67 \%$ of the total population, and the sample was divided as follows:

- Experimental group: uses the educational strategy using flipped learning style in skillful aspects under research, (40) students.

- Controlled group: uses the traditional method "explanation and presentation style" in skillful aspects under research, (40) students.

And (20) students of the total research community and outside the basic research sample as exploration sample.
Thus, the basic sample and outside the basic research sample consisted of (100) female students by $35.84 \%$ of the total population.

\section{Tools:}

1. Data recording forms: (Appendix 1): Forms for recording the measurements and data for the sample: name, age, height, weight, fitness test scores, and the skillful tests score under research in volleyball.

2. Tools and devices: Restameter device for measuring height and weight, distance tape measure, Bearings, medical balls, tennis balls, volleyballs, volleyball court.

3. Fitness elements tests: (Appendix 2, 3) The fitness elements tests for the overhead serve skill and the underhand serve skill were identified through the following references: (Ahmed Rady 2013), (Zaki 2012), (Farid et al. 2012), (Mohamed, Hamdy 2005), (Mohamed Alhefnawi 2013), (Ayman 2006), (Tarek, Ayman 2006), (Mohamed, Ayman 2005), (Ayat 2016), (Rehab et al. 2013) 
These references were used to identify:

- Fitness elements needed to perform the skills under research .

- Measurement tests for the fitness elements (physical tests).

The experts' opinion (Appendix 7) was reviewed. The experts pointed out that the fitness elements (accuracy, strength, capacity, coordination, and flexibility) Shown in Appendix (2).

The experts also pointed to the most appropriate tests for measuring these physical elements, which obtained an agreement rate higher than $75 \%$. as follows:

Aiming at overlapping rectangles test. (accuracy)

The fist strength using the dynamometer test. (Strength) push a medical $3 \mathrm{~kg}$ ball a distance test. (Capacity)

Through tennis ball on wall and receive it test. (Coordination)
Trunk bending forward down (standing. folding) test. (Frontal Flexibility)

Trunk bending up (inclined lying) test from Prone falling position.

(Background flexibility). Appendix (3).

4. Skillful tests (overhead, underhand serve): Through the following scientific studies and references: (Ayman 2006), (Tarek, Ayman 2006), (Mohamed, Ayman 2005), (Ayat 2016), (Rehab et al. 2013), (Afaf et al. 2014), (Mohamed, Hamdy 2005) The skillful tests were determined to measure the level of performance of the overhead serve and underhand serve. In addition, the expert opinion (Appendix 6) was used to determine the tests to measure the skills, Experts agreed to the tests of (overhead, underhand serve accuracy for specific places) as shown in Appendix (4). 
Table (1)

Validity and stability of physical and skillful tests

$\mathrm{N}=24$ (test validity), $\mathrm{N}=12$ (test stability)

\begin{tabular}{|c|c|c|c|c|c|c|c|c|}
\hline \multirow{2}{*}{\multicolumn{2}{|c|}{ Variables }} & \multirow[t]{2}{*}{ unit } & \multicolumn{2}{|c|}{$\begin{array}{c}\text { Distinct } \\
\mathrm{N}_{1}=12\end{array}$} & \multicolumn{2}{|c|}{$\begin{array}{c}\text { Non distinct } \\
\quad \mathrm{N}_{2}=12\end{array}$} & \multirow{2}{*}{$\begin{array}{c}\text { Mean } \\
\text { differences }\end{array}$} & \multirow{2}{*}{$\begin{array}{c}\text { T. } \\
\text { value }\end{array}$} \\
\hline & & & $\mathbf{M}$ & \pm SD & $\mathbf{M}$ & \pm SD & & \\
\hline \multicolumn{2}{|c|}{ Overhead serve test } & Degree & 12.20 & 2.21 & 6.59 & 2.19 & 5.61 & $8.60 *$ \\
\hline \multicolumn{2}{|c|}{ Underhand serve test } & Degree & 12.56 & 1.95 & 7.52 & 2.20 & 5.04 & $7.22 *$ \\
\hline \multicolumn{2}{|c|}{ Accuracy } & Degree & 5.40 & 0.84 & 3.72 & 2.05 & 1.68 & $5.17 *$ \\
\hline \multicolumn{2}{|c|}{ Strength } & $\mathrm{Kg}$ & 23.95 & 1.08 & 22.25 & 2.29 & 1.70 & $5.42 *$ \\
\hline \multicolumn{2}{|c|}{ Capacity } & meter & 4.89 & 0.41 & 3.88 & 0.45 & 1.01 & $2.14 *$ \\
\hline \multicolumn{2}{|c|}{ Coordination } & Degree & 4.85 & 0.84 & 3.20 & 0.42 & 1.65 & $2.79 *$ \\
\hline \multirow{2}{*}{ Flexibility } & Frontal & $\mathrm{Cm}$ & 7.59 & 1.02 & 5.20 & 1.22 & 2.39 & $4.68 *$ \\
\hline & Background & $\mathrm{Cm}$ & 29.69 & 1.95 & 25.49 & 1.94 & 4.20 & $9.12 *$ \\
\hline \multirow{2}{*}{\multicolumn{2}{|c|}{ Variables }} & \multirow{2}{*}{ unit } & \multicolumn{2}{|c|}{$\overline{\mathbf{1}_{\mathrm{st}}}$} & \multicolumn{2}{|c|}{$\mathbf{2}_{\text {n.d }}$} & \multirow{2}{*}{\multicolumn{2}{|c|}{$\mathbf{C C}$}} \\
\hline & & & $\mathbf{M}$ & \pm SD & $\mathbf{M}$ & \pm SD & & \\
\hline \multicolumn{2}{|c|}{ Overhead serve test } & Degree & 6.59 & 2.19 & 6.64 & 2.21 & \multicolumn{2}{|l|}{$0.93 *$} \\
\hline \multicolumn{2}{|c|}{ Underhand serve test } & Degree & 7.52 & 2.20 & 7.56 & 2.26 & \multicolumn{2}{|l|}{$0.92 *$} \\
\hline \multicolumn{2}{|c|}{ Accuracy } & Degree & 3.72 & 2.05 & 3.70 & 2.04 & \multicolumn{2}{|l|}{$0.93^{*}$} \\
\hline \multicolumn{2}{|c|}{ Strength } & $\mathrm{Kg}$ & 22.25 & 2.29 & 22.27 & 2.30 & \multicolumn{2}{|l|}{$0.92 *$} \\
\hline \multicolumn{2}{|c|}{ Capacity } & meter & 4.05 & 0.45 & 4.10 & 0.49 & \multicolumn{2}{|l|}{$0.92 *$} \\
\hline \multicolumn{2}{|c|}{ Coordination } & Degree & 3.20 & 0.42 & 3.25 & 0.44 & \multicolumn{2}{|l|}{$0.91 *$} \\
\hline \multirow{2}{*}{ Flexibility } & Frontal & $\mathrm{Cm}$ & 5.20 & 1.22 & 5.18 & 1.21 & \multicolumn{2}{|l|}{$0.95^{*}$} \\
\hline & Background & $\mathrm{Cm}$ & 25.49 & 1.94 & 25.52 & 1.96 & \multicolumn{2}{|l|}{$0.94 *$} \\
\hline
\end{tabular}

The value of t-table at a significant level $(22,0.05)=$ 2.07 (two directions), the tvalue (cc) at a significant level $(10,0.05)=0.648$ (two directions) Sperman

It is clear from Table (1) that there are statistically significant differences between the two distinct and non- distinct groups, indicating the validity of the tests. It is also evident that there is a correlation between the first and second applications indicating the stability of the tests.

The educational strategy design:

The educational strategy was designed as shown below:

1- The goal is to design an educational strategy using the flipped learning style to know its effect on the performance level of the overhead serve, 
underhand serve skill in volleyball.

2- The skillful aspects was determined by the tests under research. (Appendix 4)

3- The educational strategy content was determined of flipped learning style through the following scientific references (Ayman 2006), (Tarek, Ayman 2006), (Mohamed, Ayman 2005), (Ahmed 2007), (Suzanne 2007), (Ayat 2016), (Rehab et al. 2013), (Afaf et al. 2014), (Mohamed, Hamdy 2005), (Zaki 2012), (Farid et al. 2012), (Mohamed Alhefnawi 2013), (Mahmoud "good education" 2016), (Mahmoud "structure and policies" 2016) by including some multimedia; videos, pictures and texts in an educational group on WhatsApp Messenger in the name of "flipped learning students" contains skillful aspects of the overhead serve in volleyball. WhatsApp Messenger was chosen because of dealing ease with it and the spread of its use in mobile phones between students. Therefore, the possibility of easily browsing at any time and from anywhere.

4- The stages of the technical performance of the overhead serve skill and underhand serve skill were described (preparatory, main and final stage) (appendix 5)

5- The educational style was used in the educational strategy was the individual learning method or self-learning through using of each student for the educational group by individually.

6- The experts' opinion (appendix 6) of the educational strategy using flipped learning style was reviewed and agreement was obtained on the validity of the educational strategy and the educational group for the overhead serve skill and underhand serve skill in volleyball.

7- The educational strategy using flipped learning style was tested on a sample of the exploratory study to determine the suitability of the strategy for the sample. This experiment resulted in the clarity of all the contents of the educational strategy among the sample students of the exploratory study.

Application of the educational strategy using flipped learning style:

The educational strategy was implemented on the basic study sample according to the time distribution, as shown in appendix (7) and the following table: 
Table (2)

Time distribution of the program content for the two research groups

\begin{tabular}{l|lll}
\hline \multicolumn{1}{c|}{ Content } & \multicolumn{2}{c}{ Time } \\
\hline \hline Program Duration & 10 weeks & \\
\hline Unit Number & 10 Units & \\
\hline Unit time & $90 \mathrm{~m}$ & & \\
\cline { 2 - 4 } & Introductory & Main & Final \\
\cline { 2 - 4 } & $20 \mathrm{~m}$ & $60 \mathrm{~m}$ & $10 \mathrm{~m}$, \\
\hline \hline
\end{tabular}

- The time distribution was standardized for the two groups, and the difference was only in the learning method for each group.

- The experimental group was learn by the educational strategy using flipped learning style through, the first; students reading and seing the explanation, information and educational videos of the skillful aspects of the overhead serve skill and underhand serve skill in volleyball on the educational group (at home, for example). Then, implementation of the students

Table (3)

Distribution moderation for basic and exploratory research sample $N=100$

\begin{tabular}{l|c|c|c|c|c}
\hline \hline \multirow{2}{*}{ Parameters } & \multirow{2}{*}{ Unit } & \multicolumn{4}{|c}{ Statistical analyses } \\
\cline { 3 - 6 } & & Mean & Median & SD & SK \\
\hline \hline Age & year & 17.25 & 17.00 & 0.42 & 1.79 \\
\hline Hight & $\mathrm{Cm}$ & 160.25 & 160.00 & 1.42 & 0.53 \\
\hline Wight & $\mathrm{Kg}$ & 66.59 & 67.00 & 4.58 & -0.27 \\
\hline \hline
\end{tabular}

for what was seen in the court in college.

- The traditional group was learn by through the explanation and presentation method where the researcher first explains and presents information and knowledge about the technical aspects of the overhead serve skill and underhand serve skill in volleyball. Then, implementation of the students for what was seen in the court in college.

Moderation of sample distribution: 
Follow Table (3)

Distribution moderation for basic and exploratory research sample $N=100$

\begin{tabular}{|c|c|c|c|c|c|c|c|}
\hline \multirow{2}{*}{\multicolumn{2}{|c|}{ Parameters }} & \multirow{2}{*}{\multicolumn{2}{|c|}{ Unit }} & \multicolumn{4}{|c|}{ Statistical analyses } \\
\hline & & & & Mean & Median & SD & SK \\
\hline \multicolumn{8}{|c|}{ Physical Tests: } \\
\hline \multicolumn{2}{|l|}{ Accuracy } & \multicolumn{2}{|c|}{ degree } & 3.75 & 3.80 & 1.08 & -0.14 \\
\hline \multicolumn{2}{|l|}{ Strength } & \multicolumn{2}{|c|}{$\mathrm{Kg}$} & 22.24 & 22.30 & 2.18 & -0.08 \\
\hline \multicolumn{2}{|c|}{ Capacity } & \multicolumn{2}{|c|}{ meter } & 4.07 & 4.00 & 0.43 & 0.49 \\
\hline \multicolumn{2}{|c|}{ Coordination } & \multicolumn{2}{|c|}{ degree } & 3.22 & 3.20 & 0.44 & 0.14 \\
\hline \multirow{2}{*}{ Flexibility } & Frontal & \multicolumn{2}{|c|}{$\mathrm{Cm}$} & 5.18 & 5.00 & 1.20 & 0.45 \\
\hline & Backgroun & $\mathrm{Cn}$ & & 25.5 & 26.00 & 1.98 & -0.76 \\
\hline \multicolumn{8}{|c|}{ Skillful Tests: } \\
\hline \multicolumn{2}{|c|}{ Overhead serve test } & \multicolumn{2}{|c|}{ degree } & 6.60 & 7.00 & 2.20 & -0.55 \\
\hline Underhand & serve test & $\operatorname{degr}$ & & 7.55 & 8.00 & 2.21 & -0.61 \\
\hline \begin{tabular}{l}
\multicolumn{1}{c}{ Tabl } \\
values \\
coefficient \\
indicating
\end{tabular} & $\begin{array}{l}\text { e (3) shows } \\
\text { of } \\
\text { ranged fro } \\
\text { the m }\end{array}$ & $\begin{array}{l}\text { that the } \\
\text { cewness } \\
\text { a } \pm(3) \text {, } \\
\text { derated }\end{array}$ & & $\begin{array}{l}\text { distrib } \\
\text { explor } \\
\text { Sampl } \\
\text { measu }\end{array}$ & $\begin{array}{l}\text { ution of } \\
\text { atory san } \\
\text { le ec } \\
\text { irement) }\end{array}$ & $\begin{array}{l}\text { f the ba } \\
\text { mple. } \\
\text { quivalen } \\
\text { : }\end{array}$ & $\begin{array}{l}\text { ic and } \\
\text { (Pre- }\end{array}$ \\
\hline Equivalen & ce of the tw & resear & $\begin{array}{l}\text { Table ( } \\
\text { ch gro }\end{array}$ & $\begin{array}{l}\text { (4) } \\
\text { oups(tri }\end{array}$ & & & \\
\hline Parameters & & $\begin{array}{l}\text { Experiment } \\
\text { (the educ } \\
\text { strate } \\
40=\end{array}$ & $\begin{array}{l}\text { al group } \\
\text { ational } \\
\text { gy) } \\
\mathrm{N}\end{array}$ & $\begin{array}{r}\text { Controll } \\
\text { (explana } \\
40=\text { prese }\end{array}$ & $\begin{array}{l}\text { led group } \\
\text { ation and } \\
\text { entation) N }\end{array}$ & $\begin{array}{r}\text { Mean } \\
\text { Differenc }\end{array}$ & $\mathbf{T}$ \\
\hline & & $\mathbf{M}$ & $\mathrm{SD} \pm$ & $\mathbf{M}$ & $\mathbf{S D} \pm$ & & \\
\hline Age & & 17.22 & 0.40 & 17.26 & 0.42 & 0.04 & 1.01 \\
\hline Hight & & 160.24 & 1.4 & 160.27 & 1.43 & 0.03 & 0.98 \\
\hline Wight & & 66.57 & 4.56 & 66.62 & 4.60 & 0.05 & 1.05 \\
\hline & & Phy & sical T & Tests: & & & \\
\hline Accuracy & & 3.73 & 2.09 & 3.76 & 2.11 & 0.03 & 0.99 \\
\hline Strength & & 2.25 & 2.17 & 2.24 & 2.16 & 0.01 & 0.84 \\
\hline Capacity & & 4.08 & 0.44 & 4.06 & 0.41 & 0.02 & 0.95 \\
\hline Coordination & & 3.21 & 0.43 & 3.25 & 0.44 & 0.04 & 1.02 \\
\hline & Frontal & 5.25 & 1.25 & 5.20 & 1.22 & 0.05 & 1.08 \\
\hline Flexibility & Background & 25.51 & 1.97 & 25.52 & 1.99 & 0.01 & 0.86 \\
\hline & & & illful T & Tests: & & & \\
\hline Overhead se & ve test & 6.58 & 2.21 & 6.63 & 2.25 & 0.05 & 1.09 \\
\hline Underhand s & erve test & 7.54 & 2.22 & 7.57 & 2.24 & 0.03 & 0.97 \\
\hline
\end{tabular}


$\mathrm{T}$ Table value at a significant level $(78,0.05)=$ 2.00 (two directions)

Table (4) shows that all the values of the previous variables are not statistically significant, indicating that there are no statistically significant differences and thus the equivalence of the two research groups.

\section{Results}

Table (5)

Significance of the mean differences between the pre- post and post-post measurements of the two groups (experimental and controlled group) in the level of Overhead, Underhand serve performance in volleyball

\begin{tabular}{|c|c|c|c|c|c|c|}
\hline \multirow{3}{*}{ Parameters } & \multicolumn{4}{|c|}{$\begin{array}{c}\text { Experimental group } \\
\text { (the educational strategy) } \\
40=, \mathrm{N}\end{array}$} & \multirow{3}{*}{$\begin{array}{c}\text { Mean } \\
\text { Differences }\end{array}$} & \multirow{3}{*}{$\begin{array}{c}\mathbf{T} \\
\text { value }\end{array}$} \\
\hline & \multicolumn{2}{|c|}{ Pre } & \multicolumn{2}{|c|}{ Post } & & \\
\hline & $\mathbf{M}$ & \pm SD & $\mathbf{M}$ & \pm SD & & \\
\hline Overhead serve & 6.58 & 2.21 & 11.59 & 2.01 & 5.01 & $9.56^{*}$ \\
\hline Underhand serve & 7.54 & 2.22 & 11.97 & 1.97 & 4.43 & $8.59 *$ \\
\hline \multirow[t]{3}{*}{ Parameters } & \multicolumn{4}{|c|}{$\begin{array}{c}\text { Controlled group } \\
\text { (explanation and presentation) } \\
\mathbf{4 0}={ }_{\mathrm{r}} \mathbf{N}\end{array}$} & \multirow{3}{*}{$\begin{array}{c}\text { Mean } \\
\text { Differences }\end{array}$} & \multirow{3}{*}{$\begin{array}{c}\text { T } \\
\text { value }\end{array}$} \\
\hline & \multicolumn{2}{|c|}{ Pre } & \multicolumn{2}{|c|}{ Post } & & \\
\hline & $\mathrm{M}$ & $\pm \mathrm{SD}$ & $\mathrm{M}$ & $\pm \mathrm{SD}$ & & \\
\hline Overhead serve & 6.63 & 2.25 & 10.02 & 1.95 & 3.39 & $7.18^{*}$ \\
\hline Underhand serve & 7.57 & 2.24 & 10.56 & 1.90 & 2.99 & $6.51 *$ \\
\hline \multirow{3}{*}{ Parameters } & \multicolumn{4}{|c|}{$\begin{array}{c}\text { Post measurement } \\
80=\mathrm{N}\end{array}$} & \multirow{3}{*}{$\begin{array}{c}\text { Mean } \\
\text { Differences }\end{array}$} & \multirow{3}{*}{$\begin{array}{c}\mathbf{T} \\
\text { value }\end{array}$} \\
\hline & \multicolumn{2}{|c|}{ Experimental } & \multicolumn{2}{|c|}{ Controlled } & & \\
\hline & $\mathrm{M}$ & $\pm \mathrm{SD}$ & $\mathrm{M}$ & $\pm \mathrm{SD}$ & & \\
\hline Overhead serve & 11.59 & 2.01 & 10.02 & 1.95 & 1.57 & $3.47 *$ \\
\hline Underhand serve & 11.97 & 1.97 & 10.56 & 1.90 & 1.41 & $3.23 *$ \\
\hline
\end{tabular}

T Table value at a significant level $(39,0.05)=1.69$ (one direction)

$\mathrm{T}$ Table value at a significant level $(78,0.05)=2.00$ (one direction)
Table
(5)
shows
in post
measurements

statistically

significant

differences between Pre-Post between the two groups at a measurements of both two significant level of 0.05 .

experimental groups, as well as

\section{Discussion}


First research hypotheses: (the educational strategy using flipped learning style)

The results of Table (5) show that there are statistically significant differences between pre and post mean values of the experimental group (the educational strategy using flipped learning style) where the values of calculated $(\mathrm{t})$ $(9.56,8.59)$ are greater than the value of table (t) at a significant level (0.05), which indicates the higher level of skillful performance of Overhead, Underhand serve skills for the post measurement.

The researcher attributed the reason for these differences to the experimental variable only, which is represented in the educational strategy using flipped learning style. The researcher also attributes the progress made to the experimental group to clarifying the performance of the skillful (overhead, underhand serve skill) through The educational videos on the educational group. Thus, the higher level of skillful performance for the experimental group (the educational strategy).
This is consistent with the studies of (Atkins 2013), (Jaster 2013), (Johnson \& Renner 2016), the results of which indicate that flipped learning strategy contribute in a positive way in improving skillful performance, and active learning using technology through the educational group contributes positively to enhance skillful and physical variables under research.

Thus, the first hypothesis is achieved, which stated that there are statistically significant differences between the pre-and post-measurements for experimental group (the educational strategy using flipped learning style) in the skills level of overhead serve, underhand serve in volleyball in favor to the post measurement.

Second research hypotheses: (the traditional method "explanation and presentation style")

The results of Table (5) show that there are statistically significant differences between pre and post mean values of the controlled group in skillful performance level under research in favor to the post measurement. 
The researcher attributes the level of progress and improvement in these results to the experimental variable only, which is the use of the explanation and presentation style in skillful learning under research. This indicates that the presentation of learning in the explanation and presentation method has a positive effect on the skills level of overhead serve and underhand serve in volleyball, and knowledge of the skillful performance content through this style (explanation and presentation) that helps to form a clear picture by using of the explanation and presentation style of this skills (overhead serve, underhand serve skill).

The reason for these differences is that the style of explanation and presentation has led to the enhancement of performance during learning. Thus, benefit the students from the traditional method of teaching, and this indicates that learning by the explanation and presentation has a positive effect on skillful learning under research in volleyball.

This the previous results is consistent with (Ayat, Eman 2016), (Ayat 2009), (Zakia, Nawal and Mervat 2010) where they pointed out that the style of explanation and presentation has a positive effect on the learning of skills under research.

Thus, the second hypothesis is achieved, which stated that there are statistically significant differences between the pre-and post-measurements of the controlled group (explanation and presentation style group) in the skills level of overhead serve, underhand serve in favor to the post measurement.

\section{Third research hypotheses:}

The results of Table (5) show that there are statistically significant differences in post mean values between the two groups where the values of calculated (t) $(3.47,3.23)$ are greater than the value of table (t) at a significant level (0.05), which indicates the higher level of skillful performance for the experimental group (the educational strategy group) than the traditional method (explanation and presentation group).

This indicates that the progress in the skillful performance level of the experimental group compared to the controlled group is due to the reliance on the 
educational strategy using flipped learning style and the diversity of video, images. Thus, the positive effect on the skillful performance level due to the effectiveness of the flipped learning style.

The researcher also explains the reason for these differences to the effect of the educational strategy using flipped learning style, which helped to raise the interest of students and motivate them to exert effort during the skillful performance. Also, these differences between the two groups indicate a better understanding of the skills under research and better assimilation. Thus, the effectiveness of flipped learning style of the experimental group compared to the control group.

Thus, the researcher attributes the progress in skillful performance level for the educational strategy group to relying on the flipped learning strategy and its various the instructional videos on the educational group, this led to the improvement in skillful performance level under research. Thus, the effectiveness of the educational strategy using flipped learning style compared to the traditional method "explanation and presentation style".

Thus, it is clear from the above that the educational strategy has a positive effect on the performance level of overhead serve skill, underhand serve skill compared to the controlled group, and this is consistent with the study results (Meyer, Turner 2009), (Treglia, Platt 2010) which have pointed out that the using the flipped learning strategy leads to learning of different skills in a positive way compared to explanation and presentation style.

Therefore, the third hypothesis is achieved, which stated that there are statistically significant differences between the two groups (experimental, controlled group) in post measurements in skillful performance level under research (overhead, underhand serve skill) in favor to the experimental group (the educational strategy using flipped learning style).

\section{Conclusion}

- The educational strategy has a positive effect on the skillful 
performance level under research in volleyball.

-The explanation and presentation style has a positive effect on the skillful performance level under research in volleyball.

- The educational strategy using flipped learning style led to a higher level of skillful performance for the skills level of overhead, underhand serve in volleyball compared to the traditional method "explanation and presentation style".

\section{Recommendation:}

- Encouraging the use of the educational strategy using flipped learning style because of its effect in raising the level of skillful performance in volleyball.

- The need to holding seminars and lectures in the educational institutions to raise awareness of the importance of using flipped learning strategy in the educational process.

\section{References}

1- Ahmed Rady Elawaty: "A training program for the development of traffic forecasting components and its impact on the performance level of some defense skills for volleyball players" Unpublished Master thesis,
Faculty of Physical Education in Fleming, Alexandria University 2013.

\section{2- Ahmed Talaat Abu Zeid:}

"The impact of educational program using multimedia on cognitive achievement and the level of basic skills in volleyball for middle school students" Unpublished Master thesis, Faculty of Physical Education,

Mansoura University 2007.

3- Atkins, A.B: Turning education on its head: A study of effectiveness and student satisfaction in the flipped high school classroom. (Master's thesis). Salem College, Winston-Salem, NC, 2013.

\section{4- Ayat Abdel-Halim}

Mohamed Aly: Learning by technological modeling and its effect on the performance level of Overhead Serve skill in volleyball, Scientific Journal of Sports Sciences \& Arts. (Publications; search number 110, part 2, June 2020, ISSN 1110-8460-2020-102) at www.ijssa-gezira.com. Faculty of P.E for girls, University of Helwan, 2016.

\section{5- Ayat Abdel-Halim}

Mohamed Aly: "The Effect of an educational program on the level of skillful and knowledge of Spike in volleyball", 
Unpublished Master thesis, Faculty of Physical Education Gezera, Helwan University 2009.

6- Ayat Abdel-Halim Mohamed Aly, Eman AbdelHalim Mohamed Aly: The effect of different Teaching Styles on Learning some Volleyball Skills for Female P.E Students (Comparative Study). The international scientific Journal of Physical Education and Sport, Sciences, NSSN 24003, Print issn: 2356/9565, Online issn: 2356/9573, Volume (3), 98106, Faculty of Physical Education, Helwan University, January 2016.

7- Ayman Abdu Mohamed Mohamed: Fundamentals of Volleyball (Theory and Practice), Happy Wright for Printing and Publishing, Assiut, 2006.

8- Baker, J.W.: "The flipped learning": Using web course management tools to become the guide by the side. In Jack A. Chambers (Ed.), Selected Papers from the 11th International Conference on College Teaching and Learning, (pp. 9-17). Jacksonville, FL: Florida Community College at Jacksonville, 2010.
9- Bergmann, J., \& Sams, A.: Flip your classroom: reach every student in every class every day. International Society for Technology in Education. Retrieved from https://www.iste. org/resources/product?ID=228 5, 2012.

10- Davis, H.A., Summers, J.J., \& Miller, L.M.: An interpersonal approach to classroom management: Strategies for improving student engagement. Thousand Oaks, CA:Corwin, 2012.

\section{1- Farid Abdel Fattah} Khashaba, Hossam Khalifa, Mahmoud Metwally: Fundamentals of volleyball between theory and application, Rashid Press, second edition, Cairo, Arab Republic of Egypt. pp 45, 2012.

12- Hamdan, N., McKnight, P., McKnight, K. and Arfstrom, K.: A Review of Flipped Learning [Internet]. Available from: http://www. flippedlearning.org/cms/lib07/ VA01923112/Centricity/Doma in/41/LitReview_FlippedLearn ing.pdf [1 May 2015], 2013.

13- Jaster, R.W.: Inverting the classroom in college algebra: An examination of student perceptions and engagement and their effects on grade 
outcomes.

(Doctoral

dissertation, Texas State University-San Marcos).

Retrieved from

https://digital.library.txstate.ed u/ handle/10877/4526, 2013.

14- Johnson, L., \& Renner. J.: Effect of the flipped classroom model on a secondary computer applications course: Student and teacher perceptions, questions and student achievement. (Doctoral dissertation, University of Louisville.), 2012.

15- Justin Ferriman: 4-Step Flipped Classroom Strategy, Fortune 500 companies, training organizations, at https://www.learndash.com/ 4step-flipped-classroomstrategy/, 2016.

16- Lage, M.J., \& Platt, G.: The internet and the inverted classroom. Journal of Economic Education, 31(1), 11, 2012.

17- Lage, M.J., Platt, G. \& Treglia, M.: Inverting the classroom: A gateway to creating an inclusive learning environment. The Journal of Economic Education, 31 (1), 30-43, 2012.

18- Lajoie, S.P., \& Azevedo, R.: Teaching and learning in technology-rich environments. In P.A. Alexander, \& P.H. Winne, (Eds.). Handbook of
Educational Psychology, (2nd ed.), (pp. 803-821). New York: Routledge, 2006.

19- Mahmoud Abdel-Halim Abdel-karim: school sports system - good education, teaching skills, teacher and efficiency standards, Arab Thought House (Dar El Fikr El Araby), Cairo 2016.

20- Mahmoud Abdel-Halim Abdel-karim: school sports system - Structure and Policies, Curriculum and Curriculum, Calendar, Arab Thought House (Dar El Fikr El Araby), Cairo 2016.

21- Meyer, D., Turner, J.: Classrooms as contexts for motivating learning. In P.A. Alexander and P.H. Winne (Eds.), Handbook of Educational Psychology. (pp. 327-348), New York: NY: Routledge, 2009.

22- Mohammed Ahmed Mohammed Alhefnawi: Volleyball Training, at http://www.aun.edu.eg/arabic/ membercv. php?M_ID=3521, Faculty of Physical Education, Assiut university, 2013.

23- Mohamed Kamal El-din Al-Baroudei, Ayman Abdou Mohamed: The effect of use some teaching strategies in some fundamental skills of volley ball, Assiut university, Journal of Assiut for Science and Arts of Physical Education,2005. 
24- Mohamed, S.H., \& Hamdy, A.: The scientific bases of volleyball and measurement methods for evaluating (physically. Skill. Cognitive. Psychological. Analytical), book centre for publishing, second edition, Cairo. Arab Republic of Egypt. pp 34, 2005.

25- Mohamed, S.Z., \& Moustafa M.S.: Technology development and rehabilitation of physical education teacher. Dar El-wafaa for Publishing, second edition, Alexandria, Arab Republic of Egypt. pp 190-191, 2004.

26- Moustafa, M.S.: Teaching methods in physical education. Technical radiation library for publishing, second edition, Cairo. Arab Republic of Egypt. pp 166, 2003.

27- Rehab A. Gabal, Abdallah A. Mohamed and Khaled A. El-Battawy. "Effects of Teaching Strategy (cooperative learning and computer) on Learning the volleyball skills in P.E. Lesson". Journal of Physical Culture and Sport. Studies and Research, Warsaw, 24 ${ }^{\text {th }}$ of October 2013, Poland.

28- Suzanne $\begin{array}{r}\text { Badran } \\ \text { Sulaiman: }\end{array}$ Volleyball,
Menoufia university press, Faculty of physical education Sadat university 2007.

29- Tarek Mohamed M. Abdel-Aziz, Ayman Abdou Mohamad Mohamad: The Effectiveness of An Educational Program Using the Computer on the Level of Skill and Feedback Among Faculty of Physical Education Volleyball Players in Assiut University, Journal of Assiut for Science and Arts of Physical Education, Volume 4, April, 2006.

30- Treglia, Platt:. Inverting the classroom: A gateway to creating an inclusive learning environment. The Journal of Economic Education, 31 (1), 30-43, 2010.

31- Zakia Ibrahim Kamel, Nawal Ibrahim Shaltout, Mervat Ali Khafaja: Fundamentals of Teaching Physical Education, Technical Radiation Press (Al-eshaa Press), 2nd edition, Alexandria 2010.

32- Zaki, M.H.: Teaching volleyball methods. Technical radiation library for publishing, Cairo. Arab Republic of Egypt. pp 40, 2012. 